\title{
Chapter 7 \\ Herbonanoceuticals: A Novel Beginning in Drug Discovery and Therapeutics
}

\author{
Nidhi Saini, Abhilasha Thakur, Pawan Kaur, and Suresh Kumar Gahlawat
}

\section{Contents}

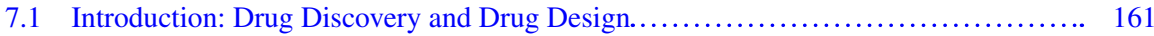

7.1.1 Herbal Phytoconstituents of Drugs............................... 163

7.1 .2 Activeness..................................................... 163

7.1.3 Methods for Discovering New Herbal Medicines......................... 163

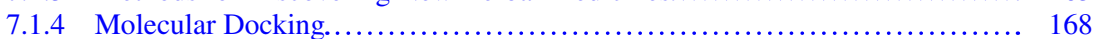

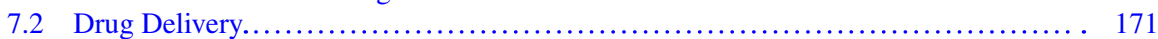

7.2.1 Nanobased Drug Delivery Systems................................... 171

7.2.2 Nanoparticles and Their Roles in Drug Delivery........................ 173

7.3 Herbonanoceuticals................................................. 177

7.4 Conclusion................................................................... 179

References. .......................................................... 180

\subsection{Introduction: Drug Discovery and Drug Design}

A typical drug discovery cycle (from lead identification through clinical trials) takes around 14 years, with a cost of US\$800 million, which makes it costly and tedious (Lavecchia and Di Giovanni 2013). Because of progress in frontline advancement, busy lifestyle, and less nutritious and unbalanced eating regimens nowadays, new generation is going up against various critical restorative issues for the duration of life. The pharmaceutical industries are fabricating high-volume and low-value/lowvolume and high-value manufactured drugs with a specific end goal to have positive or safe reaction to the body. In any case, as of late, these medications are regarded in a specific way for their indications or warnings, higher costs, nonspecificity, and other real issues like antagonism. Drug hinderance or blocking is an important issue, which may lead to death in a person. In this way, people are choosing traditional methods with a particular ultimate objective to beat these issues. Throughout Indian history, individuals have had confidence in Ayurveda, and at present Ayurveda is

\footnotetext{
N. Saini · A. Thakur · P. Kaur · S. K. Gahlawat $(\bowtie)$

Department of Biotechnology, Chaudhary Devi Lal University, Sirsa, Haryana, India
} 
drawing world's attention towards itself because it offers important restorative properties and fewer symptoms. India is a biodiverse nation, rich in restorative plants (totaling some 45,000 species_-almost $7 \%$ of the world's flowering plants) (Ali and Choudhary 2011). All parts of a plant contain bioactive compounds, which have positive physiological activity in the human body. Numerous phytochemicals are frequently gathered in the external layer of different plant tissues. These bioactive compounds are otherwise called phytoconstituents/phytochemicals/secondary metabolites, which are not supplements but assume a huge part in the plant's protective components (Doughari 2012). They are considered to have increased supplement value to be used more gainfully by the body. A celebrated expression"Prevention is better than cure"-is conceivable because of the vicinity of bioactive compounds in plants. These give shade, enhance the smell of the plants, and have advantageous effects in the body, such as elimination of free radicals (Zhang et al. 2015). Some beneficial roles of phytochemicals (which make them unique) are low toxicity, greater affordability, easy availability, biological and therapeutic properties, and raw material enabling extraction of semisynthetic chemical compounds for use in cosmetics, perfumes, etc. (Dillard and German 2000). The process of computer-aided drug design is shown in Fig. 7.1.

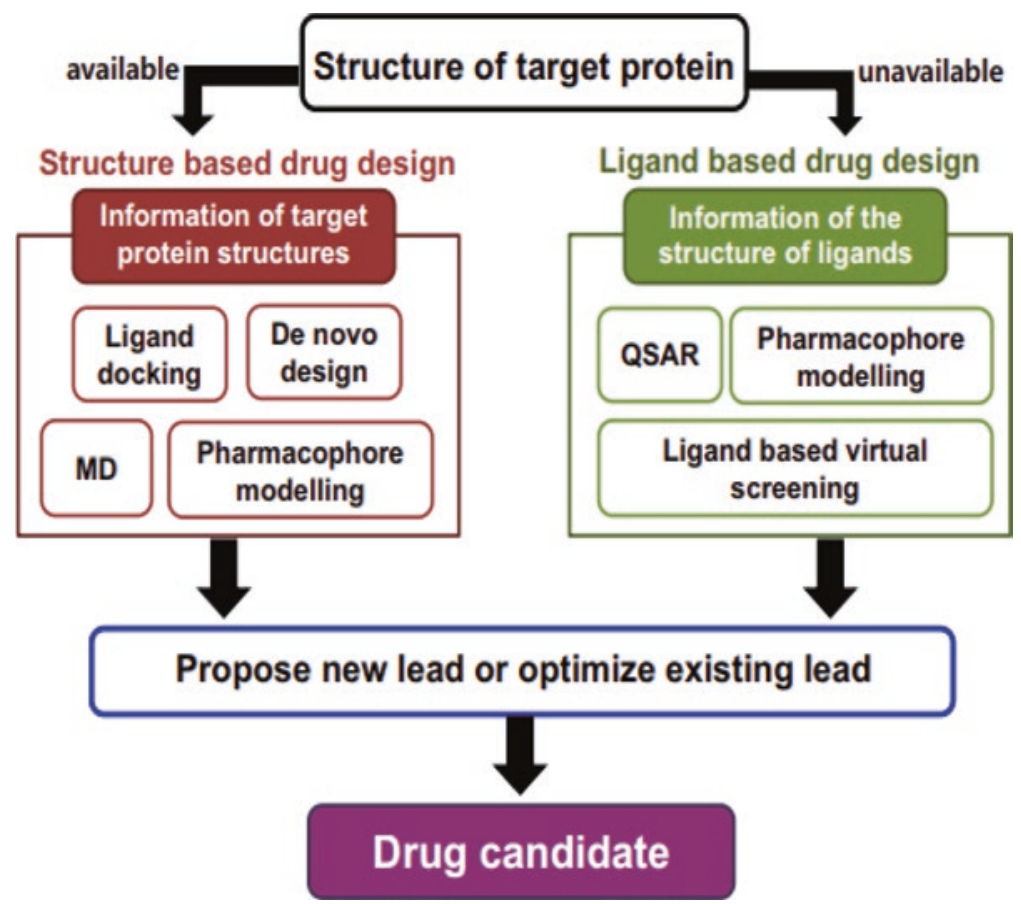

Fig. 7.1 Computer-aided drug design process (Hassan et al. 2016), showed the $M D$ molecular docking, QSAR quantitative structure-activity relationship 


\subsubsection{Herbal Phytoconstituents of Drugs}

According to the World Health Organization (WHO), herbal medicines are finished, labeled, therapeutic products that contain bioactive ingredients, aerial or underground parts of a plant or other plant material, or combinations of these (Hariharan and Subburaju 2012). According to WHO reports, $80 \%$ of people in developing countries use natural medicines for their primary health care needs (Yadav et al. 2014). Bioactive herbal compounds are used in the manufacturing of plant-based drugs, which have unique properties with long-term effects and good compatibility in the body. Alkaloids, flavonoids, phenols, tannins, terpenes, and sterols are the major phytochemicals that can be used as herbal medicines if taken in appropriate amounts. They are present in fruits and vegetables (Saxena et al. 2013). Some plant-based drugs that have been introduced in the USA over time are vincristine, vinblastine, reserpine, and deserpidine (Fabricant and Farnsworth 2001).

\subsubsection{Activeness}

The phytochemical and phytopharmacological sciences have officially established the composition and biological activities of various medicinal plant products. The vast majority of the naturally active constituents of concentrates-for example, flavonoids, tannins, and terpenoids - are very water soluble yet exhibit low assimilation, since they cannot cross lipid films, have high molecular weights, and show poor retention, causing losses of bioavailability and viability. A few investigations have demonstrated strong activity of natural medicines in vitro that is not reproducible in vivo. Besides, some fundamental substances are only occasionally utilized, in light of the fact that they are not compatible with other parts of the formulation or have bothersome properties (Bonifacio et al. 2014)

\subsubsection{Methods for Discovering New Herbal Medicines}

There are a great many phytoconstituents in nature, but they generally take many years to be identified and isolated as active compounds. Huge numbers of those that have been discovered have failed the optimization process because of their absorption, distribution, metabolism, excretion, and toxicity (ADME/Tox) inadequacies. Some may be dismissed because they fail other toxicity tests technological advances in combinational science and high-throughput screening have enabled synthesis and screening of huge libraries of compounds in a short time, reinvigorating the drug discovery process (Lavecchia and Di Giovanni 2013). To overcome these problems, researchers are working hard on various strategies for identification of promising compounds, such as virtual screening, which was first described in a peer-reviewed publication in 1997 (Hughes et al. 2011). 
Virtual screening is an exact, information-driven, compound database searching methodology, which has become increasingly prominent and has undergone rapid development in pharmaceutical research. It endeavors to discover novel compounds and chemotypes that have the necessary therapeutic and biological activities to be used as substitutes for existing ligands or, in some cases, may lead to the discovery of new ligands, structures, and homology modeling. Virtual screening is a wellordered strategy with a course of successive channels that can limit and pick an arrangement of lead-like hits with potential biological activity against proposed drug targets (Lavecchia and Di Giovanni 2013).

One of the elementary and most generally utilized methods of virtual screening is similarity searching, in which a known bioactive reference structure is sought against a database to recognize the nearest neighbor particles, since these are the most likely to display the bioactivity of interest (Holliday et al. 2011). Virtual screening can be utilized to choose compounds for screening from in-house databases and to choose which compounds to manufacture next (Kaserer et al. 2015).

Virtual screening can be divided into two general types: ligand-based virtual screening (LBVS) and structure-based virtual screening (SBVS) (Lavecchia and Di Giovanni 2013).

\subsubsection{Ligand-Based Virtual Screening}

Ligand-based virtual screening utilizes structure-activity information from an arrangement of known actives with a specific end goal to choose competitor mixes for experimental interpretation. LBVS techniques involve pharmacophore and three-dimensional (3D) shape matching, quantitative structure-activity relationships (QSARs), and likeness and substructure searches. A standout among the most well known ligand-based drug design approaches is QSAR. The objective of QSAR is to determine the connection between the basic/physicochemical properties of active compounds and their biological activity. The use of virtual screening for hit and lead identification involves a group of procedures based upon the data that he already been collected regarding the targeted and/or existing ligand earlier in the screening process. Machine learning is rapidly becoming popular in LBVS as novel calculations are proposed to manufacture precise and strong QSARs. Diverse techniques are proposed, and every technique has its own points of interest and detriments. Among these strategies, regression and classification methods-for example, multiple linear regression (MLR), nearest neighbor, naïve Bayesian classification, support vector machines, neural networks, and decision trees-are effectively connected. Discovery of novel lead compounds through computational use of experimentally determined protein structures, obtained from screening of databases through focused design exercises, is well established (Jain 2004).

Prescient models of ligand-target binding active sites can be valuable in the following circumstances:

1. Where numerous current ligands are known, but they share natural properties that reduce their organic utility 
2. Where a few ligands have been found for a target (e.g., by high-throughput screening), but they have not been widely examined, and expansion of the set is an essential objective of a medical chemistry effort (Jain 2004)

The execution of this strategy relies upon different factors-for example, preparing the planned diversity, their capacity to manage imbalanced data sets (inactive compounds typically outnumber active compounds), and parameter runs in covering active and inactive chemical space.

\subsubsection{Structure-Based Virtual Screening}

Structure-based virtual screening uses a 3D structure of the natural target (either determined tentatively by x-ray crystallography or nuclear magnetic resonance (NMR), or determined computationally through homology modeling) to dock the candidate molecules and rank them on the basis of their predicted binding affinity or complementarity to the binding site (Anderson 2003). The protein structure of interest is accessible in different databases; for example, the Research Collaboratory for Structural Bioinformatics (RCSB) Protein Data Bank (PDB) and a compound library of small molecules (available commercially or by synthesis) is investigated by docking at the active site of the biochemical target, using computer algorithms and scoring functions. Nowadays, various docking programs are commercially (or freely) accessible, with various conformational sampling algorithms and an assortment of scoring functions. Scoring of ligands is a pivotal advance in the achievement of SBVS. In spite of the fact that prediction of the ligand binding site is generally conceivable with the accessible strategies, scoring is still extremely difficult, and it is consequently hard to distinguish the right binding site or to rank compounds.

The commonly utilized scoring functions can be divided into three general classifications: force field based, knowledge based, and empirical. These capacities have ended up being fruitful for some protein-ligand associations. The basic adaptability of the objective is another essential thing to be considered as top priority because of the computational cost and multifaceted approach required to demonstrate it well (Lionta et al. 2014)

The ongoing advances and applications in SBVS-from an issue-driven point of view, with attention to docking-based virtual screening (DBVS) - are enhancing the screening library before docking; considering target adaptability, metal particles, water molecules, and other key ligand target interactions and environmental factors involved in docking; and enhancing posture/compound determination after docking (Cheng et al. 2012).

Preferably, the target site is a pocket or projection with an assortment of likely hydrogen bond donors and acceptors, hydrophobic qualities, and molecular adherence surfaces. Determining the structure of an objective protein by NMR, x-ray crystallography, or homology modeling is a major step in SBVS (Reddy et al. 2007). There are major differences between LBVS and SBVS. These differences are briefly summarized in Table 7.1. 
Table 7.1 Major differences between ligand-based virtual screening and structure-based virtual screening

\begin{tabular}{|c|c|c|c|}
\hline Aspect & $\begin{array}{l}\text { Ligand-based virtual } \\
\text { screening }\end{array}$ & Structure-based virtual screening & References \\
\hline $\begin{array}{l}\text { Three- } \\
\text { dimensional } \\
\text { protein } \\
\text { structure }\end{array}$ & Unknown & Known & $\begin{array}{l}\text { Lee et al. } \\
(2011) \text {; } \\
\text { Hassan et al. } \\
(2016)\end{array}$ \\
\hline $\begin{array}{l}\text { Drug design } \\
\text { information } \\
\text { and starting } \\
\text { point }\end{array}$ & $\begin{array}{l}\text { Drug design can be } \\
\text { based on processes } \\
\text { using the known ligands } \\
\text { of a target protein as the } \\
\text { starting point }\end{array}$ & $\begin{array}{l}\text { Reliable information on the } \\
\text { three-dimensional structure and } \\
\text { active sites of the target protein can } \\
\text { be obtained from x-ray } \\
\text { crystallography, nuclear magnetic } \\
\text { resonance, or three-dimensional } \\
\text { structure databases, and incorporated } \\
\text { into a computer model; compounds } \\
\text { binding to the target can be designed }\end{array}$ & $\begin{array}{l}\text { Lyne (2002); } \\
\text { Ferreira et al. } \\
\text { (2015) }\end{array}$ \\
\hline $\begin{array}{l}\text { Frequently } \\
\text { used } \\
\text { techniques }\end{array}$ & $\begin{array}{l}\text { Molecular similarity } \\
\text { approaches, quantitative } \\
\text { structure-activity } \\
\text { relationships, } \\
\text { pharmacophore models }\end{array}$ & $\begin{array}{l}\text { Docking, molecular dynamics } \\
\text { simulation }\end{array}$ & $\begin{array}{l}\text { Lee et al. } \\
(2011) ; \\
\text { Ekins et al. } \\
(2007)\end{array}$ \\
\hline Screening & $\begin{array}{l}\text { Databases can be } \\
\text { screened to find } \\
\text { molecules with similar } \\
\text { fingerprints by using the } \\
\text { molecular fingerprints of } \\
\text { known ligands }\end{array}$ & $\begin{array}{l}\text { Molecule database screening can be } \\
\text { done by various types of docking } \\
\text { software }\end{array}$ & $\begin{array}{l}\text { Lee et al. } \\
(2011) ; \text { Xie } \\
(2010) ;\end{array}$ \\
\hline $\begin{array}{l}\text { Process } \\
\text { involved }\end{array}$ & $\begin{array}{l}\text { Selection of the data set } \\
\text { and extraction of } \\
\text { structural/empirical } \\
\text { descriptors, variable } \\
\text { selection, model } \\
\text { construction, validation/ } \\
\text { evaluation }\end{array}$ & $\begin{array}{l}\text { An assortment of successive } \\
\text { computational stages is involved, } \\
\text { including target and database } \\
\text { preparation, docking and } \\
\text { postdocking examination, and } \\
\text { prioritization of compounds for } \\
\text { biological testing }\end{array}$ & $\begin{array}{l}\text { Lee et al. } \\
\text { (2011); } \\
\text { Cheng et al. } \\
(2012)\end{array}$ \\
\hline $\begin{array}{l}\text { Software } \\
\text { programs used } \\
\text { to perform } \\
\text { virtual } \\
\text { screening }\end{array}$ & $\begin{array}{l}\text { uNITY, MACCS-3D, } \\
\text { Catalyst, Phase, ROCS }\end{array}$ & $\begin{array}{l}\text { Glide, FlexX, Gold, AutoDock Vina, } \\
\text { AutoDock } 4.0\end{array}$ & $\begin{array}{l}\text { Hassan et al. } \\
\text { (2016) }\end{array}$ \\
\hline
\end{tabular}

\subsubsection{Virtual Screening Methods: Quantitative Structure-Activity Relationships}

Virtual screening of combinatorial libraries has attracted scrutiny lately, as its methods integrate high-throughput screening and combinatorial chemistry. A QSARbased approach is an established chemoinformatic technique for predicting and classifying biological activities of untested chemicals (Dudek et al. 2006). It is based on the general principles of medicinal science that the biological activity of a ligand or compound is identified with its molecular structure or properties, and that 
structurally similar molecules may have similar biological activities (Tong et al. 1998). QSAR models can be utilized as a part of outlining new chemical entities (NCEs) and are presently viewed as basic tools in pharmaceutical enterprises to recognize promising hits and create good-quality leads in the initial phase of drug discovery (Myint and Xie 2010).

QSARs depend on the presumption that the structure of a particle (i.e., its geometric, steric, and electronic properties) must contain the aspects that govern its physical, chemical, and organic properties, and on the capacity to represent the chemical by at least one numerical descriptor (Gramatica 2008). QSARs occur within a congeneric arrangement of compounds, affinities of ligands for their binding sites, rate constants, inhibition constants, and other biological activities either with certain structural features (Free Wilson analysis) or with atomic, group, or molecular properties-for example, lipophilicity, polarizability, electronic properties, and steric properties (Hansch analysis) (Kubinyi 1997; Mannhold et al. 2008). Together, structure-activity relationships and QSARs are referred to as (Q)SARs and fall within a scope of strategies known as in silico approaches. A (Q)SAR includes three sections: the (activity) information to be demonstrated and subsequently anticipated, information with which to show it, and a technique to figure out the model. The reasons for in silico studies are as follows (Sethi 2012):

1. To predict biological action and physicochemical properties by rational means

2. To understand and justify the mechanism of action in a series of chemicals

QSAR equations have been utilized to depict a huge number of biological activities in various series of drugs and drug ligands. Predominantly, information on enzyme inhibition is connected with the physicochemical properties of the ligands. QSAR studies can reduce the likelihood of costly failures of drug ligand research in preliminary clinical studies by separating the combinatorial libraries (i.e. seperating the collection of chemical compounds, small molecules or macromolecules like proteins which are synthesized by combinational chemistry) (Mannhold et al. 2008).

Most molecular discoveries today are the result of an iterative, three-stage process of outline, synthesis, and investigation (testing). A typical investigational process is the development of a type of model that describes the observed activity or properties to be identified with the molecular structure. Such models are typically referred to as QSARs. A QSAR includes a methodical procedure with various stages, including data set planning, molecular descriptor selection and generation, numerical or statistical model derivation, preparation and approval of a demonstration utilizing a preparation data set, and testing on a testing data set (Anderson 2003).

The general numerical formula for a QSAR is represented by the following equation

The data driving the drug design effort are progressively quantitative, expanding on new advancements in molecular structure depiction, combinatorial arithmetic, statistics, and computer simulations. Collectively these areas have led to a new QSAR paradigm in drug design (Kubinyi 1997).

The molecular descriptors utilized as a part of QSAR can be characterized as a numerical portrayal of chemical data encoded in a molecular structure through the scientific method. This scientific portrayal must be invariant to the size of the molecule anBiological Activity $=\mathrm{f}$ (Physicochemical Property). 
The data substance of structural descriptors relies upon two central aspects: (1) the molecular representation of the compound, and (2) the algorithm utilized for calculation of the descriptor.

The three noteworthy kinds of parameters first proposed are (1) hydrophobic, (2) electronic, and (3) steric (Hansch et al. 2001; Mekenyan and Veith 1994; Simon et al. 1984)

QSARs endeavor to relate physical and chemical properties of particles to their biological activities by basically utilizing easily measurable descriptors and basic statistical techniques, such as MLR, to construct a model that both depicts the activity of the data index and can anticipate activities for additional sets of untested compounds (Novotarskyi 2013). The impact of physicochemical properties on absorption (retention), distribution (dispersion), metabolism (digestion), and excretion (discharge) (ADME) is generally assessed by use of QSAR procedures (Malik et al. 2013).There are two fundamental targets for improvement of QSARs:

1. Development of predictive and robust QSARs, with a predetermined man made area, for prediction of the activity of untested molecules.

2. Creation of an informative tool by separating many examples of descriptors identified with the relevant biological activity, allowing comprehension of the components of the given biological activity. This may be helpful for identifying novel molecules with enhanced activity profiles (Nantasenamat et al. 2009).

\subsubsection{Applications of Quantitative Structure-Activity Relationships}

QSARs provide significant contributions to our understanding of the following aspects:

1. Biological activity and physicochemical parameters

2. Mechanisms of activity

3. Recognition of drug-like versus non-drug-like particles

4. Drug resistance

5. Likelihood of toxicity

6. Prediction of physicochemical properties (e.g., water solubility, lipophilicity)

7. Prediction of ADME properties (e.g., gastrointestinal retention, blood-brain barrier permeation, drug metabolism)

8. The actions of peptides

\subsubsection{Molecular Docking}

In structure-based drug design, molecular docking is a critical system, which can give an evaluation of the binding mode and, in a few applications, the binding affinity of a ligand with its receptor complex. In early docking strategies, only translational and orientational degrees of freedom of the ligand and the receptor are considered. With a rapid increase in the number of known protein crystal structures, the enthusiasm for molecular docking has increased, and many advances have been 
made in recent years (Baxter et al. 2000). Molecular docking can be achieved through two interrelated advances:

1. Testing of adaptations of the ligand at the active site of the protein

2. Ranking of these conformations by means of a scoring function (Meng et al. 2011).

The data procured against the docking framework can be used to determine the energies by active site stability, Gibb's free energy and binding energy (the energy required during the ligand-drug stabilization).

Molecular docking is helpful to clarify biomolecular interactions for rational drug design (RDD) and discovery, together with mechanical examination by setting a molecule (ligand) into the correct binding site in the target region of the DNA/protein (receptor), usually in a noncovalent form, to outline a complex of potential practicality and more prominent specificity (Dar and Khan 2016). The principal goal of molecular docking is to accomplish a ligand-receptor complex with an enhanced conformation and the least free binding energy. Appropriate use of molecular docking requires an information bank for pursuit of the main target with an appropriate PDB format and a system to plan the ligand as a PDB document (Dar and Khan 2016).

In the molecular docking strategy for investigating interactions between a ligand and a protein, the ligand is cocrystallized with the protein, and then acquisition of an x-ray structure of the complex is attempted. Despite the fact that both synthesis and crystallography can sometimes be very erratic and tedious, the technique may be feasible for small accumulations of ligands. In the event that production and crystallization attempts fail, numerous potential ligands for the protein will likely be screened. Computational molecular docking is the primary strategy chosen, and it is now well known in both the research world and industry.

In assessment of the strategy for binding a ligand protein, or demonstrating parts of the ligand, practical or beneficial theory is essential when its structure is not effectively determined by crystallography. More than 60 docking programs have been created, of which about 10 are widely utilized. The principal key element of molecular docking is a 3D structure of the protein as information. Various programs produce 3D structures of ligands and ascertain their binding parameters with the protein by figuring out the binding affinity (scoring) between the two (Andersson et al. 2010).

There are different databases available that provide data on small ligand particles-for example, the Cambridge Structural Database (CSD), Available Chemical Directory (ACD), MDL [Molecular Design Limited] Drug Data Report (MDDR), and National Cancer Institute (NCI) Database. At the time of performing docking, different interacting conformers are created and correlated with each other. In the dismissal condition, new conformers are obtained and again the search protocol proceeds until it reaches its end point after establishment of one conformation. As indicated by docking and experimental binding, affinity and free binding energy appear to be more problematic than the binding orientation. To overcome this issue, distinctive scoring functions are utilized-for example, a consensus scoring tool with a number of score capacities for the same docking posture with a specific end goal to eliminate the false positives. A huge number of attempts have been made in the advancement of successful docking conventions, and noteworthy advances have been made in computational forecasting of docking modes (Dar and Khan 2016). 
In the present docking programs, a ligand is regarded as an adaptable structure, yet the protein conformation is generally considered rigid, and water particles are not recognized in any way. The inclusion of basic water has been carefully considered, and recent investigations have demonstrated that the precision of docking is enhancing by this. The precision of docking program bundles is regularly assessed by supposed redocking tests. Redocking results are computed and assessed using the root mean square deviations (RMSDs) of the local ligand adaptation (as seen in the x-ray structure) and the ligand conformation proposed by the docking programming (docking posture) (Andersson et al. 2010). The most essential part of molecular docking is in the drug disclosure/exposure by the target, and lead enhancement. Depending on the nature and type of the disease of interest, the targets can be either protein or DNA, while drugs are generally organic small molecules.

\subsubsection{Types of Docking}

There are different sorts of molecular docking systems, including:

1. Flexible or rigid ligands/targets, depending on the goal of the docking simulations, such as adaptable ligand docking (where the target is a rigid molecule)

2. Rigid body docking, with both the target and the ligand as rigid molecules

3. Flexible docking, with both associated particles being adaptable (Dar and Khan 2016)

Table 7.2 Commonly used docking programs for virtual screening

\begin{tabular}{l|l|l|l|l}
\hline Docking method & Principles & Scoring functions & Speed & References \\
\hline DOCK & $\begin{array}{l}\text { Incremental } \\
\text { construction method }\end{array}$ & $\begin{array}{l}\text { Force field, chemical } \\
\text { complementarity } \\
\text { score, contact score }\end{array}$ & Fast & $\begin{array}{l}\text { Meng et al. (2011); } \\
\text { Ferreira et al. (2015) }\end{array}$ \\
\hline FlexX & $\begin{array}{l}\text { Incremental } \\
\text { construction method } \\
\text { eHiTS }\end{array}$ & Empirical score & Fast & $\begin{array}{l}\text { Meng et al. (2011); } \\
\text { Ferreira et al. (2015) }\end{array}$ \\
\hline FRED & Exhaustive search & Gaussian score & Fast & $\begin{array}{l}\text { Zsoldos et al. (2007); } \\
\text { Ferreira et al. (2015) }\end{array}$ \\
\hline ICM-Dock & $\begin{array}{l}\text { Stochastic global } \\
\text { optimization }\end{array}$ & $\begin{array}{l}\text { Empirical score, force } \\
\text { field based }\end{array}$ & Fast & $\begin{array}{l}\text { Meng et al. (2011); } \\
\text { Ferreira et al. (2015) }\end{array}$ \\
\hline Affinity & Monte Carlo & Force field & Slow & $\begin{array}{l}\text { Meng et al. (2011); } \\
\text { Ferreira et al. (2015) }\end{array}$ \\
\hline Glide & Systematic search & Empirical score & Fast & Ferreira et al. (2015) \\
\hline AutoDock & $\begin{array}{l}\text { Monte Carlo, genetic } \\
\text { algorithms }\end{array}$ & $\begin{array}{l}\text { Empirical score, force } \\
\text { field based }\end{array}$ & Slow & $\begin{array}{l}\text { Meng et al. (2011); } \\
\text { Ferreira et al. (2015) }\end{array}$ \\
\hline Gold & Genetic algorithms & Empirical score & Fast & $\begin{array}{l}\text { Meng et al. (2011); } \\
\text { Ferreira et al. (2015) }\end{array}$ \\
\hline QXP & Monte Carlo & Force field & Slow & $\begin{array}{l}\text { Meng et al. (2011); } \\
\text { Ferreira et al. (2015) }\end{array}$ \\
\hline
\end{tabular}


Various docking methods have recently been in use for virtual screening all over the world. These methods work on particular algorithms (scoring functions), which distinguish them from each other. Because of their characteristics (such as accuracy and speed), these are powerful tools for screening of various lead molecules/bioactive molecules. Some of the common methods, along with their various properties, are listed in Table 7.2.

\subsection{Drug Delivery}

Drug delivery is a technique for administrating a medication/pharmaceutical compound/drug to accomplish a remedial action in a living being. For a medication to have the capacity to achieve its planned clinical impact, it must first have the capacity to reach its target site of activity in the body, at an effective concentration. In the event that the medication is be applied to an outer surface (e.g., skin, ears, or eyes), it may be applied directly to the relevant surface. However, if the medication is intended to create an impact inside the body - regardless of whether it is intended to be systemic (e.g., basic antimicrobials) or aimed at particular tissues (e.g., thyroid medication) the medication must be formulated such that it can reach the circulation and be transported to the intended site(s) of its action. Medications can be delivered in various different ways. These can be mainly divided into enteral routes (e.g., sublingual, oral, and rectal); parenteral routes (e.g., subcutaneous, intramuscular, and intravenous); inhalations; and topical, transdermal, and intranasal applications. Certain unusual routes may be utilized to yield more effective results, such as intra-arterial chemotherapy administration for malignancies and intrathecal administration for focal sensory system contamination or for spinal anesthesia. These routes are significantly more perilous and clearly require more skill and care for administration of medication. There is an emerging demand for controlled release of drugs to enhance their efficacy. In this regard, the main focus of nanotechnology is on targeted and controlled-release systems for drug delivery, as summarized in Table 7.3.

\subsubsection{Nanobased Drug Delivery Systems}

The ideal drug delivery system will ensure that the conjugated or bound drug-carrier complex reaches and acts specifically at the chosen target. The focus of the drugnanocarrier complex can be active, meaning that it targets a ligand specific to the receptor or an epitope of the target tissue. Key properties of any nanomaterial utilized as a part of drug delivery are its biocompatibility and biodegradability, with an aim that the emptied transporter degrades or is transformed into nontoxic substances and eliminated from the body. The objectives of a nanoscale tranquilizer delivery system are as follows: 
Table 7.3 Targeted delivery and controlled-release drug delivery system definitions, according to experts in drug delivery

\begin{tabular}{|c|c|c|}
\hline \multicolumn{2}{|l|}{ Definitions } & \multirow[b]{2}{*}{ References } \\
\hline Targeted drug delivery & Controlled drug delivery & \\
\hline $\begin{array}{l}\text { A targeted drug delivery system is intended } \\
\text { to specifically transport medications to } \\
\text { target tissues, organs, and cells through use } \\
\text { of an assortment of drug transporters }\end{array}$ & $\begin{array}{l}\text { Controlled delivery of medications } \\
\text { improved the drug delivery } \\
\text { approaches }\end{array}$ & $\begin{array}{l}\text { Tiwari et al. } \\
(2012)\end{array}$ \\
\hline $\begin{array}{l}\text { It is generally intended to enhance the } \\
\text { pharmacological and remedial properties of } \\
\text { traditional medications and to overcome } \\
\text { problems such as limited solubility, drug } \\
\text { aggregation, poor biodispersion, and absence } \\
\text { of selectivity, controlling the drug delivery } \\
\text { carrier and lessening associated tissue injury }\end{array}$ & $\begin{array}{l}\text { Controlled delivery controls the } \\
\text { site and the rate of medication } \\
\text { release }\end{array}$ & $\begin{array}{l}\text { Tiwari et al. } \\
(2012)\end{array}$ \\
\hline $\begin{array}{l}\text { It can be intended to limit drug } \\
\text { degradation, increment bioavailability, } \\
\text { permit targeting of particular cells, and } \\
\text { diminish the total amount of medication } \\
\text { required; it can also control the delivery of } \\
\text { medication to minimize lethality and } \\
\text { unsafe reactions }\end{array}$ & $\begin{array}{l}\text { Conventional dosing regimens } \\
\text { cause fluctuations in plasma drug } \\
\text { concentrations; these changes } \\
\text { depend upon what happens to the } \\
\text { medication inside the body, such as } \\
\text { its retention, dispersion, digestion, } \\
\text { and discharge; controlled release } \\
\text { eliminates such fluctuations in } \\
\text { plasma drug concentrations }\end{array}$ & $\begin{array}{l}\text { Tiwari } \\
(2016) ; \text { Allen } \\
\text { and Cullis } \\
(2004)\end{array}$ \\
\hline $\begin{array}{l}\text { Targeted medications initially are mostly } \\
\text { utilized as a part of disease treatment; } \\
\text { optimization of the adequacy of a } \\
\text { medication is of prime significance in the } \\
\text { choice of a delivery system }\end{array}$ & $\begin{array}{l}\text { A controlled drug delivery system } \\
\text { enhances patient compliance, } \\
\text { particularly in long-term treatment } \\
\text { for persistent infections }\end{array}$ & $\begin{array}{l}\text { Zhan et al. } \\
(2017) ; \\
\text { Tiwari (2016) }\end{array}$ \\
\hline $\begin{array}{l}\text { Targeted drug delivery is a strategy for } \\
\text { administering medicine to a patient in a } \\
\text { way that restricts the concentration of the } \\
\text { medication to particular tissues }\end{array}$ & $\begin{array}{l}\text { These systems have advantages } \\
\text { over conventional drug delivery } \\
\text { systems, including limiting the } \\
\text { time of medication release, } \\
\text { safeguarding fragile medications, } \\
\text { and increasing patient comfort and } \\
\text { compliance }\end{array}$ & $\begin{array}{l}\text { Manish and } \\
\text { Vimukta } \\
\text { (2011); } \\
\text { Zadbuke } \\
\text { et al. (2013) }\end{array}$ \\
\hline $\begin{array}{l}\text { This improves the efficacy of the } \\
\text { medication while reducing its side effects }\end{array}$ & $\begin{array}{l}\text { This reduces drug doses and } \\
\text { dosing frequencies }\end{array}$ & Tiwari (2016) \\
\hline $\begin{array}{l}\text { Drug targeting is the delivery of drugs to } \\
\text { receptors or organs or any other specific } \\
\text { part of the body to which one wishes to } \\
\text { deliver the drug exclusively }\end{array}$ & $\begin{array}{l}\text { Controlled drug delivery occurs } \\
\text { when a polymer is combined with } \\
\text { a drug or active agent such that the } \\
\text { release from the bulk material is } \\
\text { predesigned }\end{array}$ & $\begin{array}{l}\text { Manish and } \\
\text { Vimukta } \\
(2011) ; \\
\text { Anupama } \\
\text { et al. (2016) }\end{array}$ \\
\hline $\begin{array}{l}\text { Targeted delivery of the drugs enhance the } \\
\text { efficacy of the drug to the target site } \\
\text { and prevents adverse effects, and increases } \\
\text { the bioavailability of the medication. }\end{array}$ & $\begin{array}{l}\text { Doses and dosing frequencies can } \\
\text { be reduced, and the required } \\
\text { plasma drug concentrations can be } \\
\text { maintained, eliminating the risk of } \\
\text { treatment failure and enhancing the } \\
\text { proficiency of treatment }\end{array}$ & $\begin{array}{l}\text { Farokhzad } \\
\text { and Langer } \\
(2009) ; \\
\text { Tiwari (2016) }\end{array}$ \\
\hline
\end{tabular}


Table 7.3 (continued)

\begin{tabular}{|c|c|c|}
\hline \multicolumn{2}{|l|}{ Definitions } & \multirow[b]{2}{*}{ References } \\
\hline Targeted drug delivery & Controlled drug delivery & \\
\hline $\begin{array}{l}\text { The focus of a drug delivery system can be } \\
\text { either passive or active; a case of passive } \\
\text { focusing is the aggregation of } \\
\text { chemotherapeutic agents in tumors because } \\
\text { of differences in the vascularization of the } \\
\text { tumor tissue versus healthy tissue; active } \\
\text { focusing includes delivery of the drug on } \\
\text { the surface of a drug transporter, enabling } \\
\text { the drug to attach specifically to diseased } \\
\text { cells }\end{array}$ & $\begin{array}{l}\text { Controlled discharge can be } \\
\text { maintained or pulsatile; maintained } \\
\text { (or persistent) delivery of a } \\
\text { medication involves polymers that } \\
\text { release the medication at a } \\
\text { controlled rate by dissemination } \\
\text { from the polymer or by } \\
\text { degradation of the polymer over } \\
\text { time; pulsatile release is frequently } \\
\text { favored, as it purposely mirrors the } \\
\text { path by which the body normally } \\
\text { creates hormones (e.g., insulin); it } \\
\text { is accomplished by utilizing } \\
\text { drug-releasing polymers that react } \\
\text { to particular stimuli (e.g., exposure } \\
\text { to light, changes in pH or } \\
\text { temperature) }\end{array}$ & $\begin{array}{l}\text { Farokhzad } \\
\text { and Langer } \\
(2009)\end{array}$ \\
\hline
\end{tabular}

(i) Targeting, to ensure that drug concentrations are highest at the intended site of action, with lower drug concentrations and fewer adverse effects in healthy tissues

(ii) Improved solubility, to optimize parenteral drug efficacy

(iii) Controlled release of drug to the target site enhace the efficacy of drug with prolonged curative activity

(iv) Sustained release of drug also extended the half life of the drug

(v) Drug movement through the blood-brain barrier and blood-cochlear barrier (Malam et al. 2009)

(vi) A delivery system that enhances patient compliance, particularly with longterm medication

(vii) An appropriate delivery system for drugs that have a short organic half-life

\subsubsection{Nanoparticles and Their Roles in Drug Delivery}

Nanoparticles are very small materials with a size range from 1 to $100 \mathrm{~nm}$. Their classification depends upon their properties, shapes, or sizes. They are mainly categorized into four groups: fullerenes, metal nanoparticles, ceramic nanoparticles, and polymeric nanoparticles. Nanoparticles are composed of three different layers: (1) a surface layer modified by various small molecules, metal ions, surfactants, and polymers; (2) a shell layer, chemically different from the core material; (3) the core of the nanoparticle (Khan et al. 2017). Nanoparticles possess remarkable physical and chemical properties, which differ from those of their bulk-sized forms, as their small 
size, large surface area, and consequently large surface-to-volume ratio improve their contact with their surroundings (Khan et al. 2011; Tiwari et al. 2012).

Nanoparticles are polymeric particles made of chemical polymers or biopolymers ranging in size from about 10 to $1000 \mathrm{~nm}(1 \mathrm{~mm})$. Drug can be encapsulated or cross linked or linked via covelant bond with polymers for sustained delivery of drug with the help of polymers. Nanoparticles and nanoformulations have already been applied as drug delivery systems with notable results and still have even greater potential for various applications, including antitumor treatment; gene therapy; acquired immune deficiency syndrome (AIDS) therapy; radiotherapy; delivery of proteins, anti-infection agents, virostatics, and vaccines; and vesicles to pass through the blood-brain barrier (Tiwari et al. 2012; Prasad et al. 2017). Herbal products have many unique properties with fewer side effects; hence, herbal nanoparticles are frequently used in drug delivery. Table 7.4 summarizes the applications of herbal nanoparticles in drug delivery.

Synthesis of nanoparticles with properties such as high monodispersity and biocompatibility is needed for a wide range of applications, from environmental to biomedical applications (Harshiny et al. 2015). Nanoparticles are the nanosized components most frequently used in nanotechnology (with a size range of 1-100 nm) and in various applications such as pharmaceuticals, electronics, cosmetics, and photonics (Prasad et al. 2016; Pandey et al. 2017).

Prominent classes of nanoparticles are carbon-based nanoparticles, ceramic nanoparticles, polymeric nanoparticles, lipid-based nanoparticles, and metal-based nanoparticles (Khan et al. 2017). For synthesis of nanoparticles, noble metals such as gold $(\mathrm{Au})$, silver $(\mathrm{Ag})$, palladium $(\mathrm{Pd})$, zinc $(\mathrm{Zn})$, copper $(\mathrm{Cu})$, and iron $(\mathrm{Fe})$ are used because of their unique $\mathrm{d}-\mathrm{d}$ transition characteristics and high localized surface plasmon resonance (LSPR) phenomena (Khan et al. 2017, Mohan et al. 2014; Dreaden et al. 2012). Gold, platinum, silver, and palladium nanoparticles $20 \mathrm{~nm}$ in size have characteristic colors of wine red, yellow, grey-black and dark black, respectively (Khan et al. 2017). Copper nanoparticles have special properties, which have made them important for various applications such as antimicrobials, catalysts, biosensors, nanoscale drugs, drug delivery, and targeted drug delivery systems (Cerda et al. 2017; Rajesh et al. 2018). Gold, silver, copper, etc., can be excellent metals for use in various biomedical applications, such as cellular imaging, photothermal therapy, and biocides (Singh et al. 2016). Nanoparticles can be synthesized to include various types of chemical reducing agents, plant extracts, or enzymes (Cerda et al. 2017; Prasad 2014). These are effective agents with low toxicity, which is especially important in the biomedical field (Rajesh et al. 2018). For synthesis of nanoparticles, a number of reducing agents are used, such as ascorbic acid, lithium aluminum hydride, and sodium borohydride (Cerda et al. 2017; Wu and Chen 2004; Tang et al. 2010). Reducing agents reduce metal ions, followed by agglomeration into clusters. These clusters eventually form metallic colloidal particles (Hussein 2016). Some nanoparticles have excellent physical and chemical properties but do not possess suitable surface properties for specific applications. Apart from the cost effectiveness of copper nanoparticles, the stability of these nanoparticles is matter of concern; therefore, it may be necessary to modify the surface of the metals (Ruckenstein and Li 2005). A common method used for surface modification of these nanoparticles is addition of suitable organic groups to the positively charged surface atoms of the metal (Kickelbick and Schubert 2003). 
Table 7.4 Applications of herbal nanoparticles in drug delivery

\begin{tabular}{|c|c|c|c|}
\hline Application & Purposes & Materials & References \\
\hline $\begin{array}{l}\text { Cancer } \\
\text { therapy }\end{array}$ & $\begin{array}{l}\text { Target design, increased } \\
\text { solubility and bioavailability, } \\
\text { reduced toxicity, greater } \\
\text { physiological compatibility, } \\
\text { cost effectiveness }\end{array}$ & $\begin{array}{l}\text { Natural products: } \beta \text {-carotene, } \\
\text { curcumin, epigallocatechin } \\
\text { gallate, genistein, resveratrol, } \\
\text { gingerol, capsaicin, paclitaxel, } \\
\text { camptothecin }\end{array}$ & $\begin{array}{l}\text { Tiwari et al. } \\
\text { (2012); } \\
\text { Gomes et al. } \\
\text { (2014) }\end{array}$ \\
\hline $\begin{array}{l}\text { Intracellular } \\
\text { targeting }\end{array}$ & $\begin{array}{l}\text { Overall drug avidity, easier } \\
\text { internalization into } \\
\text { mammalian cells, no major } \\
\text { cytotoxicity, specific } \\
\text { alterations of cellular } \\
\text { signaling and gene } \\
\text { expression }\end{array}$ & $\begin{array}{l}\text { DL-lactide-co-glycolide, } \\
\text { SIINFEKL, propiolic acid } \\
\text { N-conjugated targeting, lipids, } \\
\text { polymers, silicon, magnetic } \\
\text { materials }\end{array}$ & $\begin{array}{l}\text { Sneh-Edri } \\
\text { et al. (2011); } \\
\text { Nikalje } \\
\text { (2015); } \\
\text { Calderon- } \\
\text { Colon et al. } \\
\text { (2015) }\end{array}$ \\
\hline $\begin{array}{l}\text { Vaccine } \\
\text { adjuvants }\end{array}$ & $\begin{array}{l}\text { Delivery nanodevices are } \\
\text { faster and more sensitive with } \\
\text { better and safe way; such } \\
\text { as antigen entrapping for } \\
\text { delivery to specific cells and } \\
\text { sustained silver release } \\
\text { according to their } \\
\text { biodegradation rate; gold } \\
\text { nanoparticle adjuvant } \\
\text { recognition, absorption of } \\
\text { specific biomolecules, } \\
\text { improvement of interaction } \\
\text { with cells, and enhancement } \\
\text { of cellular uptake }\end{array}$ & $\begin{array}{l}\text { Gold nanoshells; nanoparticles } \\
\text { silicon-based nanoparticles; } \\
\text { polyethylene glycol, polyester } \\
\text { biobeads, natural polymers based } \\
\text { on polysaccharides such as } \\
\text { alginate, inulin, or chitosan; } \\
\text { virus-like particles; liposomes; } \\
\text { immune-stimulating complexes; } \\
\text { polymeric nanoparticles; } \\
\text { nondegradable nanoparticles }\end{array}$ & $\begin{array}{l}\text { Gregory et al. } \\
\text { (2013) }\end{array}$ \\
\hline $\begin{array}{l}\text { DNA } \\
\text { delivery }\end{array}$ & $\begin{array}{l}\text { Low toxicity, little } \\
\text { immunogenicity, and high } \\
\text { adaptability; efficient, } \\
\text { biocompatible, and modular }\end{array}$ & $\begin{array}{l}\text { Liposomes, dendrimers, gold } \\
\text { nanoparticles }\end{array}$ & $\begin{array}{l}\text { Abu-Salah } \\
\text { et al. }(2010)\end{array}$ \\
\hline $\begin{array}{l}\text { Ocular } \\
\text { delivery }\end{array}$ & $\begin{array}{l}\text { Improved efficiency with } \\
\text { minimal damage to } \\
\text { surrounding tissues, } \\
\text { improved safety profile, } \\
\text { better spreadability on the } \\
\text { ocular surface, enhanced } \\
\text { bioavailability due to reduced } \\
\text { drug binding to pigments, } \\
\text { sustained drug release }\end{array}$ & $\begin{array}{l}\text { Liposomes, niosomes, } \\
\text { nanomicelles, polymeric } \\
\text { nanoparticles, solid lipid } \\
\text { nanoparticles, dendrimers, } \\
\text { conjugates, calcium phosphate } \\
\text { nanoparticles }\end{array}$ & $\begin{array}{l}\text { Agarwal et al. } \\
\text { (2018) }\end{array}$ \\
\hline
\end{tabular}

In this context, surface modification can stabilize nanoparticle agglomeration, and it also modifies nanoparticles to make them compatible with another phase. For example, metal particles can be made water soluble when suitable groups are attached. A third reason for modifying nanoparticles is to enable their self-organization (Neouze and Schubert 2008; Kickelbick and Schubert 2003; Doty et al. 2005). Metal nanoparticles can be synthesized by various methods such as metal vapor synthesis, photolytic reduction, radiolytic reduction, the sonochemical method, solvent extraction reduction, the microemulsion technique, the polyol process, and alcohol reduction (Cerda et al. 2017). Physical and chemical methods are most 


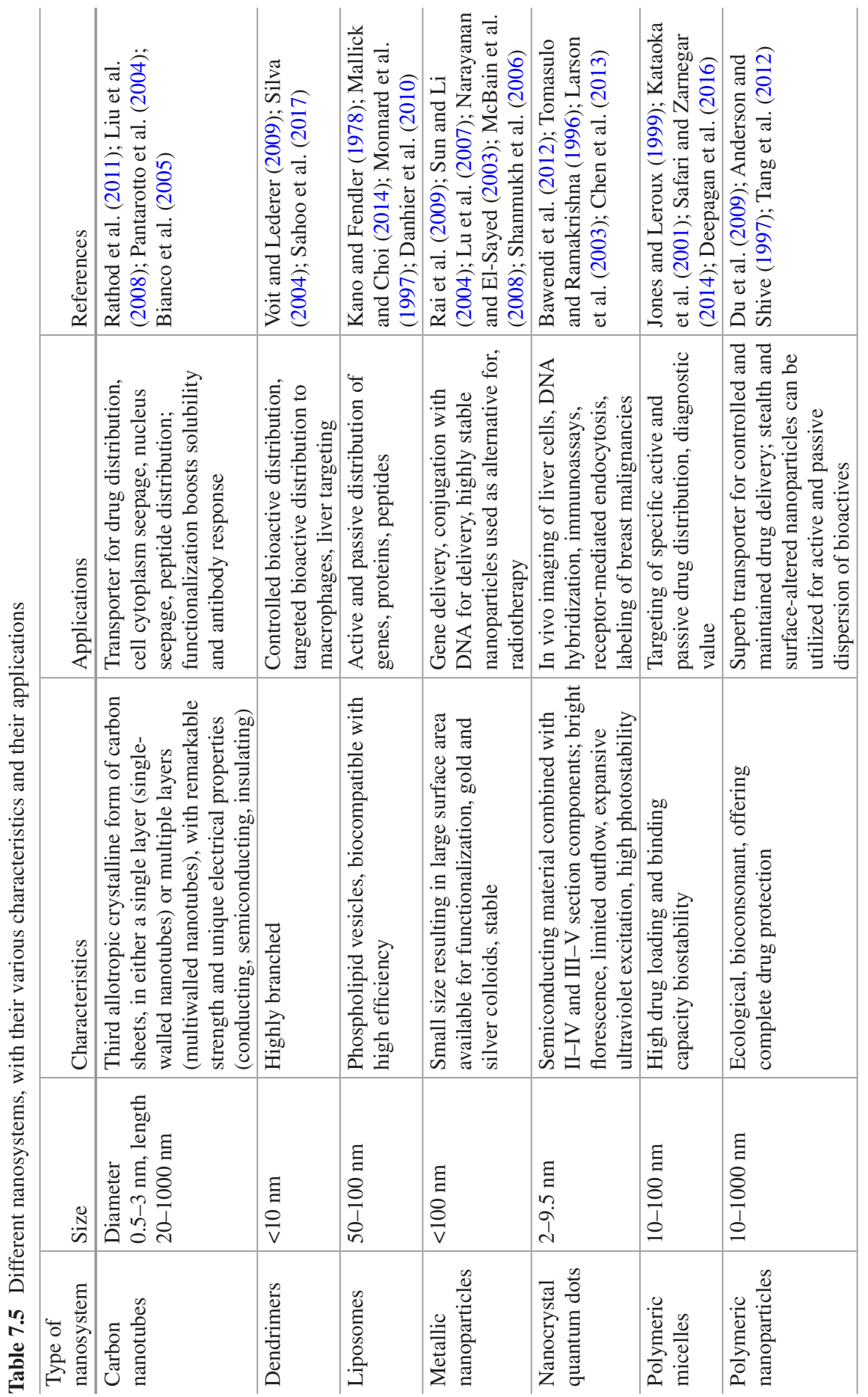


widely used for synthesis of different nanoparticles. However, the physical methods are very expensive, while the chemical methods are detrimental to the environment, as well as to living organisms (Shamaila et al. 2016). Moreover, these methods require expensive instruments, high energy, release of harmful chemicals, cell culture, and wasteful purification. The chemical reduction method has some advantages; for example, it is simple and inexpensive, and it is easy to control the size and shape of the nanoparticles. However, it has some disadvantages that can harm the environment, such as the need for disposal of noxious solvents and dangerous chemical reducing agents (Cerda et al. 2017).

Various nanosystems used in drug delivery, with their unique characteristics and their applications, are listed in Table 7.5.

\subsection{Herbonanoceuticals}

The strategy of applying nanotechnology to plant extracts has been widely cited in the literature, because nanostructured systems may potentiate the actions of plant extracts, promote sustained release of active constituents, reduce the required dose, decrease side effects, and improve activity (Bonifacio et al. 2014).Therefore, green nanosynthesis of nanoparticles has been considered rapid, nontoxic, cost effective, and environmental friendly in comparison with other chemical techniques (Harshiny et al. 2015). In green nanosynthesis of metal nanoparticles, use of (1) nontoxic chemicals used as reducing agents, (2) environmentally friendly solvents, and (3) renewable materials as stabilizing or passivating agents is very important to consider (Mohan et al. 2014; Prasad et al. 2018). Synthesis of nanoparticles using plant and plant-based biopolymers can be considered green chemistry. Plant extracts are used for metal ion reduction to form nanoparticles. Plant metabolites - such as sugars, starches, proteins, polyphenols, alkaloids, terpenoids, phenolic acids, gums, and $\beta$-cyclodextrin-play important roles in metal ion reduction into nanoparticles and their stability (Parveen and Rao 2015). In recent decades, some well known examples of carbohydrate polymers, such as chitosan, have been employed for synthesis of metal nanoparticles because of their interactions with metal ions and metal nanoparticles. With the increasing demand for adoption of sustainable and eco-friendly protocols, the use of biodegradable and nonbiodegradable precursors to prepare nanomaterials has been extensively explored. For instance, within the polysaccharide group, cyclodextrins have been applied as stabilizing agents to produce copper nanoparticles (Manivannan and Ramaraj 2012). $\beta$-Cyclodextrin is a nonreducing cyclic oligosaccharide with seven units of $\alpha$-D-glucose. The glucose rings are connected through $\alpha-(1-4)$ linkage with a hydrophilic outer surface and a hydrophobic interior cavity (Navgire et al. 2016). $\beta$-Cyclodextrin can form inclusion complexes with various organic compounds (Gogoi and Sarma Chandra 2017) and act as stabilizing agent because particles synthesized with it have the smallest size distribution. This is due to the stiff structure and low water solubility of $\beta$-cyclodextrin, causing complex precipitation easily and thereby regulating the growth of the nanoparticles (Cerda et al. 2017). 
The drawbacks of nanoparticle application in biological reactions are their poor stability and water solubility. Indeed, to prevent particle aggregation, a capping agent or stabilizing agents are used (Petralia et al. 2012). In one study, synthesis of copper nanoparticles, using $\beta$-cyclodextrin as a stabilizing agent and L-ascorbic acid as reducing agent, was done. The morphology of the synthesized $\mathrm{Cu}$ nanoparticles was characterized by advanced techniques such as transmission electron microscopy (TEM), powder X-ray diffraction (XRD), NanoDrop analysis, Fourier transform infrared spectroscopy (FTIR), dynamic light scattering (DLS), and ultraviolet-visible spectra. The antimicrobial and antibacterial properties of copper nanoparticles are checked by the use of different strains (Yadav et al. 2017).

Nanoforms of seven metals are generally utilized in Ayurveda: gold (Au), silver $(\mathrm{Ag})$, copper $(\mathrm{Cu})$, iron $(\mathrm{Fe})$, lead $(\mathrm{Pb})$, tin $(\mathrm{Sn})$, and zinc $(\mathrm{Zn})$. Applications of this old system are being rediscovered and could be of immense potential in yielding innovative metal-herb formulations that could hold promise for use in biomedicine (Galib et al. 2011). For developing such preparations, the biocompatibility and therapeutic activity of phytoconstituents present in plants play a determining role in the choice of various herbs. Such herbomineral preparations could have better curative potential because of their physiological compatibility, minimal toxicity, natural origin, easy accessibility, and lower costs. The promising applications of such nanomaterial-based herbal preparations in the field of biomedicine have led to the innovative concept of herbonanoceuticals (Gomes et al. 2014). Many studies have shown that during the processing of Ayurvedic metal-based formulations, the size of the metal particles goes down to the nanometric range (Pavani et al. 2013). Gold is used as swarna bhasma (gold ash) in different conventional Indian Ayurvedic preparations and has been characterized as having a particle size of 56-57 nm and a spherical shape. Mercury-based Ayurvedic preparations include crystalline mercuric sulfide in a 25- to 50-nm size range (Pal et al. 2014). Pavani et al. (2013) reported a modified method of bhasmikaran (a method for preparing bhasma) for preparation of iron oxide nanoparticles, which was based on green synthesis. XRD and TEM analyses have demonstrated that during use of the Ayurvedic bhasmikaran method, metal nanoparticles are formed. The metal nanoparticles, along with various phytoconstituents, can lead to better absorption and even tissue-specific targeting of therapeutic ingredients in the body. Because of their small size, these preparations are said to be more effective, as naturally synthesized metal nanoparticles do not cause toxicity in the body (Paul and Chugh 2011).

Green synthesis of metal nanoparticles could be carried out by utilizing many natural compounds, viz., vitamins, carbohydrates (sugars), phytochemicals present in plant extracts, microbes, biodegradable polymers, etc. Plant extracts are used for commercial preparation of metal nanoparticles because of the presence of phytoconstituents, which are potent reducing agents (Iravani 2011). Polyphenols are the main phytoconstituents in plant extracts that possess the ability to act as reducing agents, mainly because of their hydroxyl side chains. These can act as capping and stabilizing agents for metal nanoparticle formation. Gold nanoparticles are among the most widely utilized metal nanoparticles in the biomedical field because of their biocompatibility (Bhattacharya and Mukherjee 2008). Geetha et al. (2013) reported a rapid, economical, and single-step method for formation of gold nanoparticles, utilizing a 
flower extract from Couroupita guianensis. Green synthesis of gold nanoparticles was reported using glucoxylans of Mimosa pudica seeds to which no extra chemical stabilizing agent was added (Iram et al. 2014). Rao et al. (2016) discussed different medicinal plants and their active compounds, as well as green-synthesized metallic nanoparticles from medicinal plants, in relation to their anticancer activities. Metal nanoparticles formed using plant extracts showed enhanced tumor specificity, promising activity, and reduced toxic effects on healthy cells. The cytotoxic effects of nanoparticles are predominantly due to their large surface area, which enables efficient drug delivery, and some nanoparticles exhibit anticancer activity. However, further in vivo studies should be conducted to confirm the actual efficacy of herbal nanoparticle-based drugs (Rao et al. 2016).

Metal nanoparticles-including quantum dots, metal oxide nanoparticles, and pure metal nanoparticles-are considered useful in various biomedical applications (Bonifacio et al. 2014; Sharma and Singh 2014; Ambwani et al. 2015). Many researchers have put forward various methods for green synthesis of metal nanoparticles, employing microorganisms and plant extracts, that have been found to be eco-friendly, economical, and nontoxic (Makarov et al. 2014; Prasad et al. 2018). However, there are certain problems with metal nanoparticles, which need to be addressed prior to their commercial usage. The metal nanoparticles used for various purposes are reported to have diverse characteristics and diverse derivations, and are being utilized in various systems. However, their potential side effects in patients and the environment are yet to be thoroughly explored (Krug and Wick 2011). Contradictory biosafety considerations pertaining to metal nanoparticles have been reported in different studies (Tsoi et al. 2012; Edmundson et al. 2014; Ambwani et al. 2015).

Nanoherbal formulations can be employed for site-specific targeting of herbal medicines to enhance their selectivity, solubility, delivery, safety, and effectiveness. Nanosized drugs have an increased surface area, thereby allowing faster distribution in the blood and reduced toxicity while maintaining their therapeutic effects. The enhanced permeation and retention of nanoparticles can also help drugs to cross the blood-brain barrier (Kumar et al. 2015; Ganesan et al. 2017).

There are various therapeutic purposes of nanoparticles, which have been studied by various researchers throughout the world. Some of the applications of both herbal and synthetic nanoparticles are summarized in Table 7.6.

\subsection{Conclusion}

Since nanotechnology was first introduced and implemented in medical applications, nanomedicine has created expectations in medicinal and health applications to provide superior treatment with greater viability and specificity for certain diseases and conditions, including growth. Over the years, studies have provided details regarding the capability of nanocarriers, utilizing diverse plans to deliver anticancer therapeutic agents that are created artificially or originate from natural sources. This chapter has focused on the collaboration of nanotechnology in progressing the bioavailability of promising 
Table 7.6 Applications of various nanoparticles (herbal and synthetic) for diverse therapeutic purposes

\begin{tabular}{|c|c|c|c|}
\hline Nanoparticles used & Characteristics & $\begin{array}{l}\text { Therapeutic } \\
\text { purpose }\end{array}$ & References \\
\hline $\begin{array}{l}\text { Gold nanoshells, which } \\
\text { stimulate the appropriate } \\
\text { pro- or anti-immunity } \\
\text { pathways; silica-based } \\
\text { nanoparticles, polyethylene } \\
\text { glycol or polyester biobeads; } \\
\text { natural polymers based on } \\
\text { polysaccharides such as } \\
\text { alginate, inulin or chitosan }\end{array}$ & $\begin{array}{l}\text { Faster and more sensitive delivery } \\
\text { nanodevices; better, more secure } \\
\text { and biocompatible; entrapping of } \\
\text { antigens for delivery to specific cells } \\
\text { and controlled silver release as } \\
\text { indicated by the biodegradation rate; } \\
\text { gold nanoparticles as adjuvant, } \\
\text { assimilation of particular } \\
\text { biomolecules, improved interaction } \\
\text { with cells and cell take-up }\end{array}$ & $\begin{array}{l}\text { Vaccine } \\
\text { adjuvant }\end{array}$ & $\begin{array}{l}\text { Gregory } \\
\text { et al. (2013) }\end{array}$ \\
\hline $\begin{array}{l}\text { Herbal nanoparticles } \\
\text { containing natural } \\
\text { compounds such as } \\
\beta \text {-carotene, curcumin, } \\
\text { epigallocatechin gallate; } \\
\text { gold nanoparticles; } \\
\text { nanocapsules; fluorescent } \\
\text { nanoparticles; iron oxide } \\
\text { nanoparticles }\end{array}$ & $\begin{array}{l}\text { Target definition, increased solubility } \\
\text { and bioavailability, toxicity } \\
\text { abatement, wider physiological } \\
\text { adaptability, cost effectiveness }\end{array}$ & $\begin{array}{l}\text { Cancer } \\
\text { therapy }\end{array}$ & $\begin{array}{l}\text { Tiwari et al. } \\
\text { (2012); } \\
\text { Gomes et al. } \\
(2014)\end{array}$ \\
\hline $\begin{array}{l}\text { Liposomes, dendrimers, } \\
\text { gold nanoparticles }\end{array}$ & $\begin{array}{l}\text { Low toxicity, little immunogenicity, } \\
\text { competent, highly bioadaptable }\end{array}$ & $\begin{array}{l}\text { DNA } \\
\text { delivery }\end{array}$ & $\begin{array}{l}\text { Abu-Salah } \\
\text { et al. (2010) }\end{array}$ \\
\hline $\begin{array}{l}\text { Liposomes, niosomes, } \\
\text { nanomicelles, polymeric } \\
\text { nanoparticles, solid lipid } \\
\text { nanoparticles, dendrimers, } \\
\text { conjugates, calcium } \\
\text { phosphate nanoparticles }\end{array}$ & $\begin{array}{l}\text { Enhanced effectiveness with } \\
\text { negligible harm to surrounding } \\
\text { tissues, enhanced safety profile, better } \\
\text { spreadability on the ocular surface, } \\
\text { improved bioavailability because of } \\
\text { lessened medication binding to } \\
\text { pigments, managed drug release }\end{array}$ & $\begin{array}{l}\text { Ocular } \\
\text { delivery }\end{array}$ & $\begin{array}{l}\text { Agarwal } \\
\text { et al. (2018); } \\
\text { Brigger } \\
\text { et al. (2012) }\end{array}$ \\
\hline
\end{tabular}

phytochemicals, which may encounter delivery issues in their free-drug form. It has also shown that different natural products may yield compounds that are ideal for use in different nanoformulation systems. In any case, progress in nanomedicine-regardless of whether it is phytochemical based or synthetic based - fits to the clinical setting is advancing more slowly than expected, fundamentally because of safety issues and, in particular, the cost effectiveness of nanomedicines when the costs of manufacturing and therapeutic application are taken into consideration. In the event that these issues can be settled, phytochemical-based nanomedicines (herbonanoceuticals) may end up being favored choices for various therapeutic treatments in the future.

\section{References}

Abu Salah KM, Ansari AA, Alrokayan SA (2010) DNA-based applications in nanobiotechnology. Bio Med Res Int 715295:1-15 
Agarwal P, Huang D, Thakur SS, Rupenthal ID (2018) Nanotechnology for ocular drug delivery. In: Grumezescu AM (ed) Design of nanostructures for versatile therapeutic applications. William Andrew, Oxford, pp 137-188. https://doi.org/10.1016/B978-0-12-813667-6.00004-8

Ali MA, Choudhary RK (2011) India needs more plant taxonomists. Nature 471(7336):37

Allen TM, Cullis PR (2004) Drug delivery systems: entering the mainstream. Science 303(5665):1818-1822

Ambwani S, Tandon R, Gupta A, Ambwani TK, Chauhan RS (2015) Nanoparticles: utility, immuno-toxicology and ethical issues. J Immunol Immunopathol 17:68-78

Anderson AC (2003) The process of structure-based drug design. Chem Biol 10(9):787-797

Anderson JM, Shive MS (1997) Biodegradation and biocompatibility of PLA and PLGA microspheres. Adv Drug Deliv Rev 28(1):5-24

Andersson CD, Chen BY, Linusson A (2010) Mapping of ligand-binding cavities in proteins. Proteins: Struct Funct Bioinf 78(6): 1408-1422

Anupama S, Somashekar CN, Tamizhmani T (2016) Recent approach for drug release from matrix tablet: a review. Asian J Res Biol Pharm Sci 4(3):122-132

Bawendi MG, Kim SW, Zimmer JP (2012) Nanocrystals including III-V semiconductors. US Patent No. 8,134,175. US Patent and Trademark Office, Washington, DC

Baxter CA, Murray CW, Waszkowycz BLJ, Sykes RA, Bone RG, Perkins TDJ, Wylie W (2000) New approach to molecular docking and its application to virtual screening of chemical databases. J Chem Inf Comput Sci 40(2):254-262

Bhattacharya R, Mukherjee P (2008) Biological properties of "naked" metal nanoparticles. Adv Drug Deliv Rev 60:1289-1306

Bianco A, Kostarelos K, Partidos CD, Prato M (2005) Biomedical applications of functionalised carbon nanotubes. Chem Commun 5:571-577

Bonifacio BV, Silva PB, Ramos MA, Negri KM, Bauab TM, Chorilli M (2014) Nanotechnologybased drug delivery systems and herbal medicines: a review. Int J Nanomedicine 9:1-15

Brigger I, Dubernet C, Couvreur P (2012) Nanoparticles in cancer therapy and diagnosis. Adv Drug Deliv Rev 64:24-36

Calderon-Colon X, Raimondi G, Benkoski JJ, Patrone JB (2015) Solid lipid nanoparticles (SLNs) for intracellular targeting applications. J Vis Exp 105. https://doi.org/10.3791/53102

Cerda SJ, Gomez EH, Nunez AG, Rivero IA, Ponce GY, Lopez FLZ (2017) A green synthesis of copper nanoparticles using native cyclodextrins as stabilizing agents. J Saudi Chem Soc 21(3):341-348

Chen O, Zhao J, Chauhan VP, Cui J, Wong C, Harris DK, Wei H, Han HS, Fukumura D, Jain RK, Bawendi MG (2013) Compact high-quality CdSe-CdS core-shell nanocrystals with narrow emission linewidths and suppressed blinking. Nat Mater 12(5):445

Cheng T, Li Q, Zhou Z, Wang Y, Bryant SH (2012) Structure-based virtual screening for drug discovery: a problem-centric review. AAPS J 14(1):133-141

Danhier F, Feron O, Preat V (2010) To exploit the tumor microenvironment: passive and active tumor targeting of nanocarriers for anti-cancer drug delivery. J Control Release 148(2):135-146

Dar AM, Khan S (2016) Spectroscopic, viscositic, DNA binding and cytotoxic studies of newly synthesized steroidal imidazolidines. J Fluoresc 26(2):639-649

Deepagan VG, Kwon S, You DG, Um W, Ko H, Lee H, Jo DG, Kang YM, Park JH (2016) In situ diselenide-crosslinked polymeric micelles for ROS-mediated anticancer drug delivery. Biomaterials 103:56-66

Dillard CJ, German JB (2000) Phytochemicals: nutraceuticals and human health. J Sci Food Agric 80(12):1744-1756

Doty RC, Tshikhudo TR, Brust M, Fernig DG (2005) Extremely stable water-soluble Ag nanoparticles. Chem Mater 17(18):4630-4635

Doughari JH (2012) Phytochemicals: extraction methods, basic structures and mode of action as potential chemotherapeutic agents. In: Rao V (ed) Phytochemicals - a global perspective of their role in nutrition and health . InTechOpen. https://doi.org/10.5772/26052

Dreaden EC, Alkilany AM, Huang X, Murphy CJ, El-Sayed MA (2012) The golden age: gold nanoparticles for biomedicine. Chem Soc Rev 41(7):2740-2779 
Du WL, Niu SS, Xu YL, Xu ZR, Fan CL (2009) Antibacterial activity of chitosan tripolyphosphate nanoparticles loaded with various metal ions. Carbohydr Polym 75(3):385-389

Dudek AZ, Arodz T, Galvez J (2006) Computational methods in developing quantitative structureactivity relationships (QSAR): a review. Comb Chem High Throughput Screen 9(3):213-228

Edmundson MC, Capeness M, Horsfall L (2014) Exploring the potential of metallic nanoparticles within synthetic biology. New Biotechnol 31(6):572-578

Ekins S, Mestres J, Testa B (2007) In silico pharmacology for drug discovery: applications to targets and beyond. Br J Pharmacol 152(1):21-37

Fabricant DS, Farnsworth NR (2001) The value of plants used in traditional medicine for drug discovery. Environ Health Perspect 109(1):69

Farokhzad OC, Langer R (2009) Impact of nanotechnology on drug delivery. ACS Nano 3(1):16-20

Ferreira LG, dos Santos RN, Oliva G, Andricopulo AD (2015) Molecular docking and structurebased drug design strategies. Molecules 20(7):13384-13421

Galib BM, Mashru M, Jagtap C, Patgiri BJ, Prajapati PK (2011) Therapeutic potentials of metals in ancient India: a review through Charaka Samhita. J Ayurveda Integr Med 2:55-63

Ganesan P, Arulselvan P, Choi DK (2017) Phytobioactive compound-based nanodelivery systems for the treatment of type 2 diabetes mellitus—current status. Int J Nanomedicine 12:1097-1111

Geetha R, Ashokkumar T, Tamilselvan S, Govindaraju K, Sadiq M (2013) Green synthesis of gold nanoparticles and their anticancer activity. Cancer Nanotechnol 4:91-98

Gogoi A, Sarma KC (2017) Synthesis of the novel $\beta$-cyclodextrin supported $\mathrm{CeO}_{2}$ nanoparticles for the catalytic degradation of methylene blue in aqueous suspension. Mater Chem Phys 194:327-336

Gomes A, Ghosh S, Sengupta J, Datta P, Gomes A (2014) Herbonanoceuticals: a new step towards herbal therapeutics. Med Aromat Plants 3:162

Gramatica P (2008) A short history of QSAR evolution. http://qsarworld.com/TempFileupload/ Shorthistoryofqsar.pdf. Accessed 25th May, 2018

Gregory AE, Williamson D, Titball R (2013) Vaccine delivery using nanoparticles. Front Cell Infect Microbiol 3:13

Hansch C, Kurup A, Garg R, Gao H (2001) Chem-bioinformatics and QSAR: a review of QSAR lacking positive hydrophobic terms. Chem Rev 101(3):619-672

Hariharan P, Subburaju T (2012) Medicinal plants and its standardization—a global and industrial overview. Global J Med Plant Res 1(1):10-13

Harshiny M, Iswarya CN, Matheswaran M (2015) Biogenic synthesis of iron nanoparticles using Amaranthus dubius leaf extract as a reducing agent. Powder Technol 286:744-749

Hassan Baig M, Ahmad K, Roy S, Mohammad Ashraf J, Adil M, Haris Siddiqui M, Khan S, Khan MA, Provaznik I, Choi I (2016) Computer aided drug design: success and limitations. Curr Pharm Des 22(5):572-581

Holliday JD, Kanoulas E, Malim N, Willett P (2011) Multiple search methods for similarity-based virtual screening: analysis of search overlap and precision. J Cheminf 3(1):29

Hughes JP, Rees S, Kalindjian SB, Philpott KL (2011) Principles of early drug discovery. Br J Pharmacol 162(6):1239-1249

Hussein AK (2016) Applications of nanotechnology to improve the performance of solar collectors-recent advances and overview. Renew Sust Energ Rev 62:767-792

Iram F, Iqbal MS, Athar MM, Saeed MZ, Yasmeen A (2014) Glucoxylan mediated green synthesis of gold and silver nanoparticles and their phytotoxicity study. Carbohydr Polym 104:29-33

Iravani S (2011) Green synthesis of metal nanoparticles using plants. Green Chem 13:2638-2650

Jain AN (2004) Ligand-based structural hypotheses for virtual screening. J Med Chem 47(4):947-961

Jones MC, Leroux JC (1999) Polymeric micelles-a new generation of colloidal drug carriers. Eur J Pharm Biopharm 48(2):101-111

Kano K, Fendler JH (1978) Pyranine as a sensitive $\mathrm{pH}$ probe for liposome interiors and surfaces: pH gradients across phospholipid vesicles. Biochim Biophys Acta Biomembr 509(2):289-299 
Kaserer T, Temml V, Kutil Z, Vanek T, Landa P, Schuster D (2015) Prospective performance evaluation of selected common virtual screening tools. Case study: cyclooxygenase (COX) 1 and 2. Eur J Med Chem 96:445-457

Kataoka K, Harada A, Nagasaki Y (2001) Block copolymer micelles for drug delivery: design, characterization and biological significance. Adv Drug Deliv Rev 47(1):113-131

Khan SB, Faisal M, Rahman MM, Jamal A (2011) Exploration of $\mathrm{CeO}_{2}$ nanoparticles as a chemisensor and photo-catalyst for environmental applications. Sci Total Environ 409(15):2987-2992

Khan I, Saeed K, Khan I (2017) Nanoparticles: properties, applications and toxicities. Arab J Chem. https://doi.org/10.1016/j.arabjc.2017.05.011

Kickelbick G, Schubert US (2003) Advances in nanophase materials and nanotechnology. Functionalization and Surface Treatment of Nanoparticles, MI Baraton, Ed, 91-102

Krug HF, Wick P (2011) Nanotoxicology: an interdisciplinary challenge. Angew Chem Int Ed 50:1260-1278

Kubinyi H (1997) QSAR and 3D QSAR in drug design part 1: methodology. Drug Discov Today 2(11):457-467

Kumar P, Kulkarni PK, Srivastava AA (2015) Pharmaceutical application of nanoparticles in drug delivery system. J Chem Pharm Res 7:703-712

Larson DR, Zipfel WR, Williams RM, Clark SW, Bruchez MP, Wise FW, Webb WW (2003) Water-soluble quantum dots for multiphoton fluorescence imaging in vivo. Science 300(5624):1434-1436

Lavecchia A, Di Giovanni C (2013) Virtual screening strategies in drug discovery: a critical review. Curr Med Chem 20(23):2839-2860

Lee CH, Huang HC, Juan HF (2011) Reviewing ligand-based rational drug design: the search for an ATP synthase inhibitor. Int J Mol Sci 12(8):5304-5318

Lionta E, Spyrou GK, Vassilatis D, Cournia Z (2014) Structure-based virtual screening for drug discovery: principles, applications and recent advances. Curr Top Med Chem 14(16): 1923-1938

Liu Z, Chen K, Davis C, Sherlock S, Cao Q, Chen X, Dai H (2008) Drug delivery with carbon nanotubes for in vivo cancer treatment. Cancer Res 68(16):6652-6660

Lu AH, Salabas EE, Schuth F (2007) Magnetic nanoparticles: synthesis, protection, functionalization, and application. Angew Chem Int Ed 46(8):1222-1244

Lyne PD (2002) Structure-based virtual screening: an overview. Drug Discov Today 7(20): $1047-1055$

Makarov VV, Love AJ, Sinitsyna OV, Makarova SS, Yaminsky IV, Taliansky ME, Kalinina NO (2014) Green nanotechnologies: synthesis of metal nanoparticles using plants. Acta Nat 6:35-44

Malam Y, Loizidou M, Seifalian AM (2009) Liposomes and nanoparticles: nanosized vehicles for drug delivery in cancer. Trends Pharmacol Sci 30(11):592-599

Malik JK, Soni H, Singhai AK (2013) QSAR—application in drug design. Int J Pharm Res Allied Sci 2(1):1-13

Mallick S, Choi JS (2014) Liposomes: versatile and biocompatible nanovesicles for efficient biomolecules delivery. J Nanosci Nanotechnol 14(1):755-765

Manish G, Vimukta S (2011) Targeted drug delivery system: a review. Res J Chem Sci 1(2):135-138

Manivannan S, Ramaraj R (2012) Synthesis of cyclodextrin-silicate sol-gel composite embedded gold nanoparticles and its electrocatalytic application. Chem Eng J 210:195-202

Mannhold R, Krogsgaard-Larsen P, Timmerman H (2008) QSAR: Hansch analysis and related approaches, vol 1. $\mathrm{VCH}$, Weinheim

McBain SC, Yiu HH, Dobson J (2008) Magnetic nanoparticles for gene and drug delivery. Int J Nanomedicine 3(2):169

McGann M (2011) FRED pose prediction and virtual screening accuracy. J Chem Inf Model 51(3):578-596

Mekenyan OG, Veith GD (1994) The electronic factor in QSAR: MO-parameters, competing interactions, reactivity and toxicity. SAR and QSAR in Environ Res 2(1-2):129-143

Meng XY, Zhang HX, Mezei M, Cui M (2011) Molecular docking: a powerful approach for structure-based drug discovery. Curr Comput Aided Drug Des 7(2):146-157 
Mohan S, Oluwafemi OS, George SC, Jayachandran VP, Lewu FB, Songca SP, Kalarikkal N, Thomas S (2014) Completely green synthesis of dextrose reduced silver nanoparticles, its antimicrobial and sensing properties. Carbohydr Polym 106:469-474

Monnard PA, Oberholzer T, Luisi P (1997) Entrapment of nucleic acids in liposomes. Biochim Biophys Acta Biomembr 1329(1):39-50

Myint KZ, Xie XQ (2010) Recent advances in fragment-based QSAR and multi-dimensional QSAR methods. Int J Mol Sci 11(10):3846-3866

Nantasenamat C, Isarankura-Na-Ayudhya C, Naenna T, Prachayasittikul V (2009) A practical overview of quantitative structure-activity relationship. EXCLI J 8:74-88

Narayanan R, El-Sayed MA (2003) Effect of catalysis on the stability of metallic nanoparticles: Suzuki reaction catalyzed by PVP-palladium nanoparticles. J Am Chem Soc 125(27):8340-8347

Navgire ME, Gogoi P, Mallesham B, Rangaswamy A, Reddy BM, Lande MK (2016) $\beta$-Cyclodextrin supported $\mathrm{MoO}_{3}-\mathrm{CeO}_{2}$ nanocomposite material as an efficient heterogeneous catalyst for degradation of phenol. RSC Adv 6(34):28679-28687

Neouze MA, Schubert U (2008) Surface modification and functionalization of metal and metal oxide nanoparticles by organic ligands. Monatshefte fur Chemie-Chem Mon 139(3):183-195

Nikalje AP (2015) Nanotechnology and its applications in medicine. Med Chem 5(2):081-089

Novotarskyi S (2013) QSAR approaches to predict human cytochrome P450 inhibition. Doctoral dissertation, Technische Universität München

Pal D, Sahu CK, Haldar A (2014) Bhasma: the ancient Indian nanomedicine. J Adv Pharm Technol Res 5:4-12

Pandey RK, Kawabata Y, Teraji S, Norisuye T, Tran-Cong-Miyata Q, Soh S, Nakanishi H (2017) Metal nanowire-based hybrid electrodes exhibiting high charge/discharge rates and long-lived electrocatalysis. ACS Appl Mater Interfaces 9(41):36350-36357

Pantarotto D, Briand JP, Prato M, Bianco A (2004) Translocation of bioactive peptides across cell membranes by carbon nanotubes. Chem Commun 1:16-17

Parveen A, Rao S (2015) Cytotoxicity and genotoxicity of biosynthesized gold and silver nanoparticles on human cancer cell lines. J Clust Sci 26(3):775-788

Paul S, Chugh A (2011) Assessing the role of Ayurvedic bhasmas as ethno-nanomedicine in the metal based nanomedicine patent regime. J Intellect Disabil Res 16:509-515

Pavani T, Chakra CS, Rao KV (2013) A green approach for the synthesis of nano-sized iron oxide, by Indian Ayurvedic modified bhasmikaran method. Am J Pharm Sci 1:1-7

Petralia S, Barbuzzi T, Ventimiglia G (2012) Polymerase chain reaction efficiency improved by water soluble $\beta$-cyclodextrins capped platinum nanoparticles. Mater Sci Eng C 32(4): $848-850$

Prasad R (2014) Synthesis of silver nanoparticles in photosynthetic plants. J Nanopart:963961. https://doi.org/10.1155/2014/963961

Prasad R, Pandey R, Barman I (2016) Engineering tailored nanoparticles with microbes: quo vadis. WIREs Nanomed Nanobiotechnol 8:316-330. https://doi.org/10.1002/wnan.1363

Prasad R, Pandey R, Varma A, Barman I (2017) Polymer based nanoparticles for drug delivery systems and cancer therapeutics. In: Kharkwal H, Janaswamy S (eds) Natural polymers for drug delivery. CAB International, UK, pp 53-70

Prasad R, Jha A, Prasad K (2018) Exploring the realms of nature for nanosynthesis. Springer International Publishing. ISBN:978-3-319-99570-0. https://www.springer.com/978-3-319-99570-0

Rai M, Yadav A, Gade A (2009) Silver nanoparticles as a new generation of antimicrobials. Biotechnol Adv 27(1):76-83

Rajesh KM, Ajitha B, Reddy YAK, Suneetha Y, Reddy PS (2018) Assisted green synthesis of copper nanoparticles using Syzygium aromaticum bud extract: Physical, optical and antimicrobial properties. Optik 154:593-600

Rao PV, Nallappan D, Madhavi K, Rahman S, Wei LJ, Gan S (2016) Phytochemicals and biogenic metallic nanoparticles as anticancer agents. Oxid Med Cell Longevity 2016:3685671, 15. https://doi.org/10.1155/2016/3685671 
Rathod KB, Patel MB, Parmar PK, Kharadi SR, Patel PV, Patel KS (2011) Glimpses of current advances of nanotechnology in therapeutics. Int J Pharm Pharm Sci 3:8-12

Reddy AS, Pati SP, Kumar PP, Pradeep HN, Sastry GN (2007) Virtual screening in drug discovery-a computational perspective. Curr Protein Pept Sci 8(4):329-351

Ruckenstein E, Li ZF (2005) Surface modification and functionalization through the self-assembled monolayer and graft polymerization. Adv Colloid Interf Sci 113(1):43-63

Safari J, Zarnegar Z (2014) Advanced drug delivery systems: nanotechnology of health design: a review. J Saudi Chem Soc 18(2):85-99

Sahoo SK, Misra R, Parveen S (2017) Nanoparticles: a boon to drug delivery, therapeutics, diagnostics and imaging. In: Balogh LP (ed) Nanomedicine in cancer. Pan Stanford, Singapore, pp 73-124

Saxena M, Saxena J, Nema R, Singh D, Gupta A (2013) Phytochemistry of medicinal plants. J Pharmacogn Phytochem 1(6):168-182

Sethi NS (2012) A review on computational methods in developing quantitative structure-activity relationship (QSAR). Int J Drug Res Technol 2(2):189-197

Shamaila S, Zafar N, Riaz S, Sharif R, Nazir J, Naseem S (2016) Gold nanoparticles: an efficient antimicrobial agent against enteric bacterial human pathogen. Nano 6(4):71

Shanmukh S, Jones L, Driskell J, Zhao Y, Dluhy R, Tripp RA (2006) Rapid and sensitive detection of respiratory virus molecular signatures using a silver nanorod array SERS substrate. Nano Lett 6(11):2630-2636

Sharma C, Singh C (2014) Nano carriers of novel drug delivery system for Ayurveda herbal remedies need of hour: a bird's eye view. Am J Pharm Tech Res 4:60-69

Silva GA (2004) Introduction to nanotechnology and its applications to medicine. Surg Neurol 61(3):216-220

Simon Z, Chiriac A, Holban S, Ciubotariu D, Mihalas G (1984) Minimum steric difference: the MTD method for QSAR studies. Chemometrics research studies series. Research Studies Press, Letchworth

Singh P, Kim YJ, Zhang D, Yang DC (2016) Biological synthesis of nanoparticles from plants and microorganisms. Trends Biotechnol 34(7):588-599

Sneh-Edri H, Likhtenshtein D, Stepensky D (2011) Intracellular targeting of PLGA nanoparticles encapsulating antigenic peptide to the endoplasmic reticulum of dendritic cells and its effect on antigen cross-presentation in vitro. Mol Pharm 8(4):1266-1275

Sun X, Li Y (2004) Colloidal carbon spheres and their core/shell structures with noble-metal nanoparticles. Angew Chem 116(5):607-611

Tang H, Lin Y, Andrews C, Sodano HA (2010) Nanocomposites with increased energy density through high aspect ratio PZT nanowires. Nanotechnology 22(1):015702

Tang F, Li L, Chen D (2012) Mesoporous silica nanoparticles: synthesis, biocompatibility and drug delivery. Adv Mater 24(12):1504-1534

Tiwari R (2016) Controlled release drug formulation in pharmaceuticals: a study on their application and properties. World J Pharm Res 5:1740-1720

Tiwari G, Tiwari R, Sriwastawa B, Bhati L, Pandey S, Pandey P, Bannerjee SK (2012) Drug delivery systems: an updated review. Int J Pharm Invest 2(1):2

Tomasulo A, Ramakrishna MV (1996) Quantum confinement effects in semiconductor clusters. II. J Chem Phys 105(9):3612-3626

Tong W, Lowis DR, Perkins R, Chen Y, Welsh WJ, Goddette DW, Heritage TW, Sheehan DM (1998) Evaluation of quantitative structure activity relationship methods for large-scale prediction of chemicals binding to the estrogen receptor. J Chem Inf Comput Sci 38(4):669-677

Tsoi KM, Dai Q, Alman BA, Chan WCW (2012) Are quantum dots toxic? Exploring the discrepancy between cell culture and animal studies. Acc Chem Res 46:662-671

Voit BI, Lederer A (2009) Hyperbranched and highly branched polymer architectures synthetic strategies and major characterization aspects. Chem Rev 109(11):5924-5973

Wu SH, Chen DH (2004) Synthesis of high-concentration Cu nanoparticles in aqueous CTAB solutions. J Colloid Interface Sci 273(1):165-169 
Xie XQS (2010) Exploiting PubChem for virtual screening. Expert Opin Drug Discovery 5(12): $1205-1220$

Yadav M, Bhatia VJ, Doshi G, Shastri K (2014) Novel techniques in herbal drug delivery systems. Int J Pharm Sci Rev Res 28:83-89

Yadav L, Tripathi RM, Prasad R, Pudake RN, Mittal J (2017) Antibacterial activity of cu nanoparticles against E. coli, Staphylococcus aureus and Pseudomonas aeruginosa. Nano Biomed Eng 9(1):9-14. https://doi.org/10.5101/nbe.v9i1.p9-14

Zadbuke N, Shahi S, Gulecha B, Padalkar A, Thube M (2013) Recent trends and future of pharmaceutical packaging technology. J Pharm Bioallied Sci 5(2):98

Zhan J, Ting XL, Zhu J (2017) The research progress of targeted drug delivery systems. IOP Conf Ser Mater Sci Eng 207(1):012017

Zhang YJ, Gan RY, Li S, Zhou Y, Li AN, Xu DP, Li HB (2015) Antioxidant phytochemicals for the prevention and treatment of chronic diseases. Molecules 20(12):21138-21156

Zsoldos Z, Reid D, Simon A, Sadjad SB, Johnson AP (2007) eHiTS: a new fast, exhaustive flexible ligand docking system. J Mol Graph Model 26(1):198-212 